\title{
Effects of catchment disturbance on stream invertebrates: comparison of different habitats (vegetation, benthic and interstitial) using bio-ecological groups.
}

\author{
P.E. Sarriquet ${ }^{1}$, Y.R. Delettre ${ }^{1,2}$, P. Marmonier ${ }^{1,2^{*}}$ \\ ${ }^{1}$ UMR-CNRS 6553 ECOBIO, Université de Rennes I, Av. du Général Leclerc, Bât. 14A, Campus Beaulieu 35042 Rennes Cedex, France. \\ ${ }^{2}$ Station Biologique de Paimpont, 35380 Paimpont, France.
}

\begin{abstract}
The intensification of agriculture has drastically modified the structure of rural landscapes, changing field size, destructing hedgerow networks, and increasing nutrients and fine sediments fluxes to rivers. To evaluate the effects of these disturbances at the catchment scale, we studied the surface and interstitial water chemistry and the invertebrate assemblages in three different habitats: the vegetation, the benthic, and the interstitial. Six headwater streams ranging from undisturbed to disturbed forests (wind-fallen area) and from traditional agriculture to intensive farming areas were studied. Differences between forested and agricultural streams lie in changes in water chemistry, in habitat quality, and in the composition of the assemblages with little reduction in species richness. The forested streams were only disturbed by large-scale modifications of their catchments (i.e. wind-fallen area along the stream), which made the invertebrate assemblages similar to those of agricultural streams, even if water characteristics were not modified. In contrast, large scale modifications of landscape structure near the agricultural streams (hedgerow removal) had little effect on the fauna, but the destruction of the riparian strip (with direct access of the cattle to the river) profoundly affected the system with drastic modifications of in-stream habitat quality and invertebrate assemblage composition. The effects of these disturbances differed according to the habitat considered, with increasing differences between assemblages from the interstitial, to the benthic, and to the vegetation habitats. Finally, groups of organisms based on bioecological traits appeared as efficient tools for the evaluation of catchment disturbances, at least for the benthic and the vegetation fauna.
\end{abstract}

Keywords: Disturbance, Biodiversity, Land-cover, Agriculture, Hyporheic.

\section{Introduction}

Since 1950, changes in agriculture have deeply modified landscape structure with several negative consequences on aquatic communities (Harding et al. 1998, Hunsaker \& Levine 1995, Allan \& Johnson 1997, Gregel et al. 2002), sometimes difficult to distinguish from other landscape features (e.g. geology, Richards et al. 1997). The modification of farming practices and the reduction of hedgerow networks generate an increase in solute inputs to the streams (Arheimer \& Liden 2000, Van Herpe \& Troch 2000), with potential oxygen depletion and river eutrophication (Mulholland et al. 1984, Gulis \& Suberkropp 2003). The increase in field size and the destruction of riparian vegetation also induce an increase

\footnotetext{
* Corresponding author: E-mail : pierre.marmonier@univrennes1.fr
}

in fine sediment inputs into streams (Stevens \& Cummins 1999, Quinn \& Stroud 2002), with potential stream bed clogging (Culp et al. 1983, Quinn et al. 1992, Hancock 2002), changes in the chemical characteristics of interstitial water (Dahm et al. 1998) and in the composition of interstitial assemblages (Boulton et al. 1998). The destruction of riparian woody buffer generates a decrease in leaf litter inputs (Stone \& Wallace 1998, Mc Kie \& Cranston 2001), that modifies community composition (decrease of shredders), but increases light availability for aquatic vegetation and phytophilous invertebrates (increase in habitat availability; Habbija et al. 2002). Even in forests, human activities (like logging) induce an increase in sediments inputs into streams by soil scouring (Benfield et al. 2001, Collier \& Smith 2005) or through road construction (Sidle et al. 2004), with changes in the composition of invertebrate communities and in organic matter availability (Webster \& Waide 
1982). Thus, changes in land-cover in both agricultural and forested streams have combined effects at the catchment scale (e.g. changes in nutrient fluxes, organic matter quality) and at the habitat scale (e.g. development of vegetation patches, sediment clogging).

The aim of this study was to evaluate the effect of a growing level of disturbance on the macro-invertebrate assemblages, combining catchments and habitats. We chose six headwater streams ranging on a gradient from little (forest) to highly disturbed sites (intensive agriculture) and we sampled the macro-invertebrates of three different habitats: the aquatic vegetation, the benthic, and the interstitial layers (hyporheic zone). To compare the responses of the fauna of these three habitats to increasing disturbance, we analysed (1) the changes in water chemistry and sediment characteristics along the gradient, (2) the links between stream characteristics and assemblage composition using co-inertia analyses, and (3) the changes in the structure of the assemblages using the groups of organisms based on bio-ecological traits proposed by Usseglio-Polatera et al. (2001).

\section{Material and methods}

\section{Study site}

The study site was located in Northern Brittany, South of the Mont Saint Michel Bay (France, 48 4'N; 1 ${ }^{\circ}{ }^{\prime} \mathrm{W}$; Fig. 1). The Pleine-Fougères site is a Long Term Ecological Research (LTER) area where agriculture is dominated by milk and cereals production. Agriculture intensification have induced here drastic changes in landscape structure (Burel et al. 2003, Meeus, 1993), that resulted in an heterogeneous landscape, ranging from small forests, to grassland, and to area of intensive culture of vegetables or maize. Six headwater streams with similar granite sandy substrate were sampled in April 2003, three located in the Villecartier state-owned forest (noted F) and three located along an agricultural gradient (noted A).

Catchment land-cover was evaluated with a Geographical Information System (Arcview 3.2 $2^{\mathrm{TM}}$ ) using IGN (the French National Geographic Institute) digital maps, aerial photographs and field validation (INRA, SAD-Armorique). Nine different cover classes were recorded: woodlands, water bodies, fallow land, planted, sown and permanent meadows, maize, other crops (mostly vegetables) and built areas (mainly roads and houses). A 200m-wide buffer strip was defined along each river, in which each cover type was recorded to assess the landscape composition.

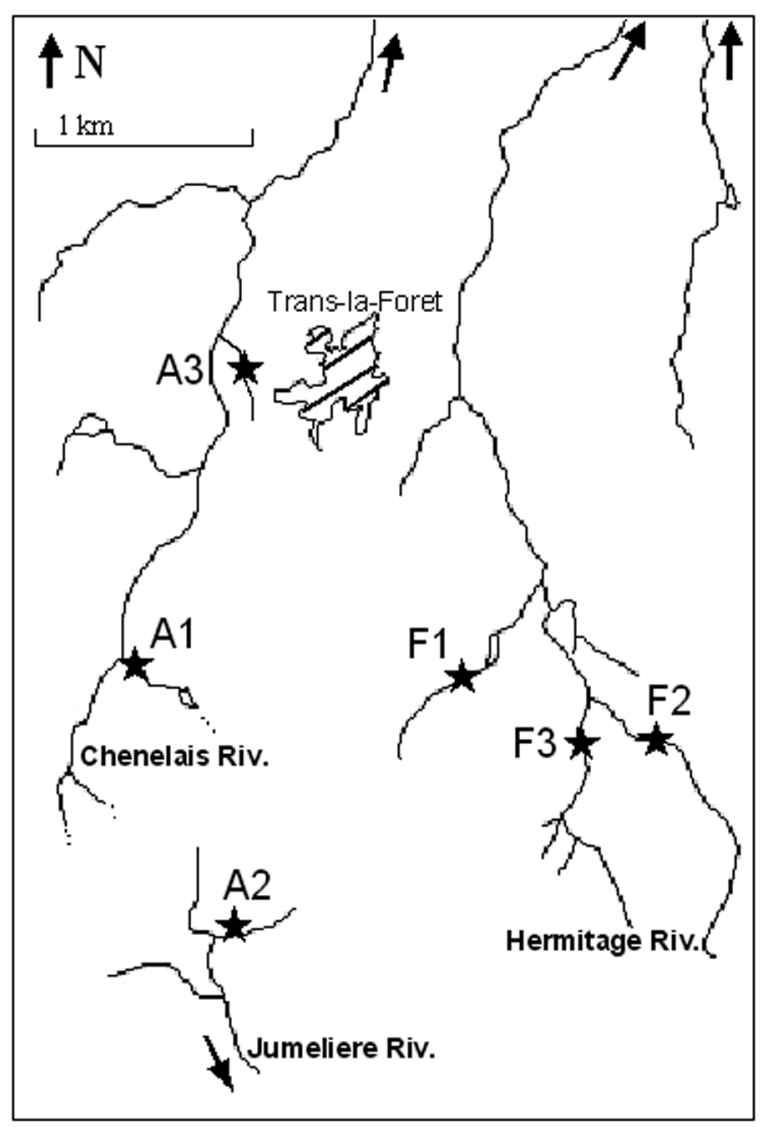

Fig. 1. Location of the study streams within the Pleine-Fougère LTER area. F: forested stream; A: agricultural stream; 1: undisturbed catchment; 2 : intermediate; 3 : disturbed catchment.

The three forested streams were all springs of the Petit Hermitage River surrounded by beeches (Fagus sylvaticus) and oaks (Quercus ilex). Station F1 was located in an undisturbed forested area, the river bottom was white clean sand with numerous patches of moss (mostly Fontinalis sp.). Station F2 was surrounded by the same type of forest but with several forest roads, and the bottom sediment presented a medium level of fine sediments (particularly blue clay) and scarce moss patches. The station F3 was disturbed by a wind fallen area due to a storm seven years ago. The bottom sediment was strongly modified, with an important increase in fine particles and a dense layer of aquatic macrophytes (mostly Veronica beccabunga L.).

The A1 stream was one of the springs of the Chenelais River that drained an agricultural catchment mostly covered by permanent grassland with a dense hedgerow network a wet riparian zone that isolated the stream 
from the fields. A barbed wire along the channel prevented the direct access of cows to the stream. The bottom was made of coarse clean sand, scarce moss patches, and woody debris. The Jumeliere River (noted A2) corresponded to a medium level of disturbance. It was located in an open field area dominated by permanent and temporary grasslands and maize crop fields. It was lined with barbed wire to prevent the direct access of cows to the channel. Sediment was a mix of coarse sand and silt, covered by numerous aquatic macrophyte patches. Finally, the A3 stream, another Chenelais spring, was surrounded by temporary grassland, cereal, and maize crop fields and was located in a low-land area. Cows had a direct access to the channel $100 \mathrm{~m}$ upstream of the station and trampled the stream bottom. This last station was characterized by a high content in fine sediments (silt and clay) and dense patches of aquatic and semi-aquatic vegetation.

\section{Physical and chemical characteristics}

In each stream, depth, width, type of vegetation (moss, aquatic macrophyte, semi-aquatic vegetation), and dominant benthic substrate were observed. Sediments $(500 \mathrm{~g})$ were collected directly in the river bed in four locations at each station. Surface water was sampled four times from upstream to downstream of the station directly in open water. The interstitial water was sampled in four points using mini-piezometers $(1.2 \mathrm{~m}$ long PVC pipes, diameter $=1.5 \mathrm{~cm}$ and $5 \mathrm{~cm}$ of screen length, Boulton 1993) inserted to a depth of $20 \mathrm{~cm}$ within the sediment. We measured dissolved oxygen content (mg/L; WTW OXY 92), temperature, electrical conductivity ( $\mu \mathrm{S} / \mathrm{cm}$; WTW LF92), $\mathrm{pH}$ (pH-meter: IQ, scientific Instrument) in both surface and interstitial waters, and current velocity in the open water and inside vegetation.

In the laboratory, water samples were filtered (Whatman GF/C, $1.2 \mu \mathrm{m}$ pore size) before analysis by colorimetric methods: indophenol blue for ammonium (NH4N; Rossum \& Villaruz 1963), diazotation for nitrites (NO2-N, Barnes \& Kollard 1951), molybdate-antimony for soluble reactive phosphorus (SRP; Murphy \& Riley 1975) and for nitrate (NO3-N) after a reduction of nitrate to nitrite by activated cadmium followed by nitrite titration. Grain size was measured on dried samples (48 hours, $\left.105^{\circ} \mathrm{C}\right)$ and results were expressed in percentage of fine $(<200 \mu \mathrm{m})$, medium (between 0.2 and $1 \mathrm{~mm}$ ) and coarse particles $(>1 \mathrm{~mm})$. The total organic matter (TOM) was evaluated by loss on ignition (4 hours, $550^{\circ} \mathrm{C}$; Bretschko \& Leichtfried 1987) and expressed in percentage of organic matter.

\section{Fauna}

Three different habitats were sampled for fauna with four replicates in each habitat: the aquatic vegetation (into plants, herbaceous bank vegetation, or aquatic moss) the benthic layer (at the sand surface in the centre of the channel), and the interstitial habitat (at $-20 \mathrm{~cm}$ deep below the sand surface). For both benthic and vegetation habitats, we used a mini Surber net $(200 \mu \mathrm{m}$ mesh size, area sampled $=0.03 \mathrm{~m}^{2}$ ). For interstitial fauna, 3 litres of water were collected in 4 points from at least 3 nested mini-piezometers using an URCHIN pump. Samples were filtered ( $200 \mu \mathrm{m}$ mesh size), preserved in the field (5\% formaldehyde solution) and interstitial ones were stained with Bengal Pink. Invertebrates were sorted in the laboratory and identified to species or genus level when possible, except for most Diptera (family level), copepods (separated in Cyclopoida and Harpacticoida), Nematoda and Oligochaeta (not identified any further).

\section{Biological and ecological traits}

Biological and ecological traits of species were documented using the works of Usseglio-Polatera et al. (2000), Charvet et al. (2000) and synthetic tables from Tachet et al. (2000). Organisms were ranged into six homogeneous groups in terms of biological and ecological traits (Usseglio-Polatera et al. 2001, Table 1). The group $\alpha 1$ was excluded of this study, because it was represented by only few individuals of the genera Rhithrogena and Siphonoperla in the forested streams. The total abundances and the mean relative taxonomic richness of the six groups based on bio-ecological traits were calculated for each sample, together with the H' Shannon diversity index.

\section{Statistical analyses}

A total of 48 samples were collected for water chemistry and 72 for fauna. The differences between rivers for mean abundances, mean taxonomic richness and diversities, mean richness and diversities in the bio-ecological trait groups $(n=4)$ were analysed using non parametric ANOVA of rank (Kruskal-Wallis test, H). The use of pseudo-replicates is a limit of this study. Land-cover and physico-chemical data were analysed using principal components analysis (PCA), followed by Ascendant Hierarchical Classification (AHC) to determine station typologies based on these parameters. Each class obtained was characterized by its average value for the following co-inertia analyses. Different environmental characteristics were used for the different habitats: (1) catchment land-cover, surface water chemistry, and grain size of surface sediments were used for the benthic 
Table 1. Biological and ecological traits of organisms divided into the six functional groups

\begin{tabular}{|c|c|c|c|c|c|c|c|}
\hline \multirow[b]{2}{*}{ groups } & \multirow[b]{2}{*}{ size } & \multirow[b]{2}{*}{ food } & \multirow[b]{2}{*}{$\begin{array}{l}\text { Feeding } \\
\text { habits }\end{array}$} & \multirow[b]{2}{*}{ Saprobity } & \multirow[b]{2}{*}{$\begin{array}{l}\text { Trophic } \\
\text { status }\end{array}$} & substratum & \multirow[b]{2}{*}{$\begin{array}{l}\text { Current } \\
\text { velocity }\end{array}$} \\
\hline & & & & & & $\begin{array}{l}\text { Transversal } \\
\text { distribution }\end{array}$ & \\
\hline \multirow{2}{*}{$\alpha 2$} & \multirow{2}{*}{ Medium } & \multirow{2}{*}{$\begin{array}{c}\text { Micro- and } \\
\text { macrophytes } \\
\text { Macroinvertebrates }\end{array}$} & \multirow{2}{*}{$\begin{array}{l}\text { Scrappers } \\
\text { and } \\
\text { shredders }\end{array}$} & \multirow{2}{*}{$\begin{array}{c}\text { Seno- to } \\
\text { oligosaprobic }\end{array}$} & \multirow[t]{2}{*}{ Oligotrophic } & $\begin{array}{l}\text { Coarse mineral } \\
\text { substrate }\end{array}$ & \multirow{2}{*}{$\begin{array}{l}\text { Medium } \\
\text { to high }\end{array}$} \\
\hline & & & & & & Channel & \\
\hline \multirow[t]{2}{*}{$\beta$} & \multirow{2}{*}{$\begin{array}{l}\text { Small to } \\
\text { medium }\end{array}$} & \multirow{2}{*}{$\begin{array}{c}\text { Micro- and } \\
\text { macrophytes } \\
\text { Macroinvertebrates }\end{array}$} & \multirow{2}{*}{$\begin{array}{l}\text { Scrappers } \\
\text { and } \\
\text { shredders }\end{array}$} & \multirow{2}{*}{$\begin{array}{l}\text { Oligo- to } \beta \text { - } \\
\text { mesosaprobic }\end{array}$} & \multirow{2}{*}{$\begin{array}{l}\text { Oligo- to } \\
\text { mesotrophic }\end{array}$} & $\begin{array}{l}\text { Variable mineral } \\
\text { substrate }\end{array}$ & \multirow{2}{*}{$\begin{array}{l}\text { Medium } \\
\text { to high }\end{array}$} \\
\hline & & & & & & Channel or banks & \\
\hline \multirow[t]{2}{*}{$\gamma 1$} & \multirow{2}{*}{ Small } & \multirow[t]{2}{*}{ Living microphytes } & \multirow[t]{2}{*}{ Scrappers } & \multirow{2}{*}{$\begin{array}{l}\text { Oligo- to } \beta \text { - } \\
\text { mesosaprobic }\end{array}$} & \multirow{2}{*}{$\begin{array}{l}\text { Oligo- to } \\
\text { mesotrophic }\end{array}$} & $\begin{array}{l}\text { Wide substrate } \\
\text { preference }\end{array}$ & \multirow[t]{2}{*}{ Medium } \\
\hline & & & & & & Channel or banks & \\
\hline \multirow[t]{2}{*}{$\gamma 2$} & \multirow[t]{2}{*}{ Medium } & \multirow[t]{2}{*}{ Macrophytes } & \multirow[t]{2}{*}{ Scrappers } & \multirow{2}{*}{$\begin{array}{c}\beta- \\
\text { mesosaprobic }\end{array}$} & \multirow{2}{*}{$\begin{array}{l}\text { Oligo- to } \\
\text { mesotrophic }\end{array}$} & $\begin{array}{l}\text { Medium to small } \\
\text { mineral substrate }\end{array}$ & \multirow[t]{2}{*}{ Slow } \\
\hline & & & & & & banks & \\
\hline \multirow[b]{2}{*}{$\delta 2$} & \multirow[b]{2}{*}{ Medium } & \multirow[b]{2}{*}{$\begin{array}{l}\text { Living } \\
\text { invertebrates }\end{array}$} & & & & $\begin{array}{l}\text { Wide substrate } \\
\text { preference }\end{array}$ & \\
\hline & & & $\begin{array}{l}\text { Piercers or } \\
\text { shredders }\end{array}$ & Mesosaprobic & Mesotrophic & $\begin{array}{c}\text { Banks or } \\
\text { diconnected side- } \\
\text { arms }\end{array}$ & Slow \\
\hline & & Microphytes & Filter or & & & Fine organic sed. & \\
\hline$\zeta$ & Variable & Fine detritus & $\begin{array}{l}\text { deposit } \\
\text { feeders }\end{array}$ & Polysaprobic & Variable & $\begin{array}{l}\text { Banks or pools } \\
\text { (groundwater) }\end{array}$ & slow \\
\hline
\end{tabular}

layer, (2) catchment land-cover, surface water chemistry, and vegetation types were used for the vegetation habitat, finally (3) catchment land-cover and interstitial water chemistry were used for the interstitial habitat. Co-inertia analyses were used to compare the link between fauna and environmental characteristics in the three different habitats (Doledec \& Chessel 1994). It is a simultaneous ordination of two tables based on a covariance matrix, which projects on the same co-inertia space the two first axes of the Principal Component Analysis (PCA) on environmental factors and of the Multiple Correspondence Analysis (MCA) on faunal assemblages. Significance was tested using Monte-Carlo random permutation tests. Co-inertia analyses were performed using ADE- $4^{\mathrm{TM}}$ software (Thioulouse et al. 1995).

\section{Results}

\section{Densities and diversities}

A total of 6,132 individuals and 78 taxa were collected in the benthic habitat, 17,251 individuals and 98 taxa in the vegetation, and 1150 individuals and 29 taxa in the interstitial habitat, with only two stygobyte species (hypogean organisms adapted to groundwater): the Amphipoda Niphargus aquilex Schiödte and a Bathynellidae (Crustacea, Syncarida).

In the benthic layer, forested streams had a significantly higher mean taxonomic richness than agricultural streams (Table 2). Mean densities did not significantly changed between stations, while mean taxonomic richness and $\mathrm{H}$ ' index for the taxonomic groups were significantly higher in the forested than in the agricultural streams (with highest values measured in the stream F2). In the vegetation, mean abundances significantly differ between stations (Table 2), with the highest densities in the disturbed stations F3 and A3. In contrast, vegetation fauna of the forested and agricultural streams did not significantly differ for the taxonomic richness (pertypes and per stations) and the $\mathrm{H}^{\prime}$ diversity. Finally in the interstitial habitat, mean densities significantly varied between stations, with low values in the forested streams F1 and F2 and high values in the disturbed stream A3. The density of individuals sampled in the sediments of the stream F3 
Table 2. Densities, taxonomic richness, and diversities of invertebrate assemblages in the two land-cover types (forested versus agricultural contexts) and in the six stations (F1 to A3). Abundances are expressed in number of individuals per $0.03 \mathrm{~m}^{2}$ for benthic and vegetation habitats and in number of individuals per 3 litres for the interstitial habitat. $\mathrm{H}^{\prime}$ diversity index was calculated for the distribution of individuals in taxonomic units or in bio-ecological groups. K-W test: Krusfal-Wallis ANOVA of rank (*: $\mathrm{p}<0.05)$

\begin{tabular}{|c|c|c|c|c|c|c|c|}
\hline & \multicolumn{3}{|c|}{ Forested context } & \multicolumn{3}{|c|}{ Agricultural context } & \multirow{2}{*}{$\begin{array}{r}\text { K-W } \\
\text { test }\end{array}$} \\
\hline & F1 & F2 & F3 & A1 & A2 & A3 & \\
\hline $\begin{array}{l}\text { Benthic fauna } \\
\text { Mean taxonomic richness } \\
\text { per land-cover type }( \pm \text { s.d.) }\end{array}$ & & $\begin{array}{l}19.5 \\
(4.2)\end{array}$ & & & $\begin{array}{l}15.2 \\
(5.3)\end{array}$ & & $*$ \\
\hline Number of taxa restricted to one land-cover type & & 27 & & & 21 & & \\
\hline $\begin{array}{l}\text { Mean densities per station } \\
( \pm \text { s.d. })\end{array}$ & $\begin{array}{c}90 \\
(31)\end{array}$ & $\begin{array}{c}189 \\
(135\end{array}$ & $\begin{array}{c}272 \\
(199)\end{array}$ & $\begin{array}{c}269 \\
(381)\end{array}$ & $\begin{array}{l}120 \\
(60)\end{array}$ & $\begin{array}{c}609 \\
(237)\end{array}$ & n.s. \\
\hline $\begin{array}{l}\text { Mean taxonomic richness } \\
\text { per station ( } \pm \text { s.d.) }\end{array}$ & $\begin{array}{l}16.7 \\
(3.3)\end{array}$ & $\begin{array}{l}21.0 \\
(3.6)\end{array}$ & $\begin{array}{l}20.7 \\
(5.3)\end{array}$ & $\begin{array}{l}12.2 \\
(4.3)\end{array}$ & $\begin{array}{l}12.7 \\
(3.4)\end{array}$ & $\begin{array}{l}20.5 \\
(3.7)\end{array}$ & $*$ \\
\hline $\mathrm{H}^{\prime}$ for taxonomic diversity per station ( \pm s.d.) & $\begin{array}{l}3.2 \\
(0.4)\end{array}$ & $\begin{array}{c}3.4 \\
(0.5)\end{array}$ & $\begin{array}{c}3.2 \\
(0.5)\end{array}$ & $\begin{array}{l}2.6 \\
(0.3)\end{array}$ & $\begin{array}{l}2.0 \\
(0.6)\end{array}$ & $\begin{array}{l}2.9 \\
(0.3)\end{array}$ & $*$ \\
\hline $\begin{array}{l}\text { H' for bio-ecological diversity per station } \\
( \pm \text { s.d. })\end{array}$ & $\begin{array}{l}2.0 \\
(0.3)\end{array}$ & $\begin{array}{l}2.2 \\
(0.6)\end{array}$ & $\begin{array}{l}1.9 \\
(0.3)\end{array}$ & $\begin{array}{c}1.5 \\
(0.1)\end{array}$ & $\begin{array}{l}1.5 \\
(0.5)\end{array}$ & $\begin{array}{l}1.8 \\
(0.2)\end{array}$ & $*$ \\
\hline $\begin{array}{l}\text { Vegetation fauna } \\
\text { Mean taxonomic richness } \\
\text { per land-cover type ( } \pm \text { s.d.) }\end{array}$ & & $\begin{array}{l}25.3 \\
(4.8)\end{array}$ & & & $\begin{array}{l}22.6 \\
(4.8)\end{array}$ & & n.s. \\
\hline Number of taxa restricted to one land-cover type & & 24 & & & 30 & & \\
\hline $\begin{array}{l}\text { Mean densities per station } \\
( \pm \text { s.d. })\end{array}$ & $\begin{array}{l}540 \\
(264)\end{array}$ & $\begin{array}{c}461 \\
(172)\end{array}$ & $\begin{array}{l}1192 \\
670)\end{array}$ & $\begin{array}{l}559 \\
(246)\end{array}$ & $\begin{array}{c}466 \\
(147)\end{array}$ & $\begin{array}{l}1627 \\
(315)\end{array}$ & $*$ \\
\hline Mean taxonomic richness per station ( \pm s.d.) & $\begin{array}{l}23.2 \\
(5.2)\end{array}$ & $\begin{array}{l}25.5 \\
(4.1)\end{array}$ & $\begin{array}{l}27.2 \\
(5.6)\end{array}$ & $\begin{array}{l}23.2 \\
(5.8)\end{array}$ & $\begin{array}{c}21 \\
(4.4)\end{array}$ & $\begin{array}{l}23.5 \\
(5.1)\end{array}$ & n.s. \\
\hline $\mathrm{H}^{\prime}$ for taxonomic diversity per station ( \pm s.d.) & $\begin{array}{c}3.4 \\
(0.5)\end{array}$ & $\begin{array}{l}3.6 \\
(0.4)\end{array}$ & $\begin{array}{l}3.5 \\
(0.2)\end{array}$ & $\begin{array}{l}3.1 \\
(0.6)\end{array}$ & $\begin{array}{l}3.1 \\
(0.4)\end{array}$ & $\begin{array}{l}2.8 \\
(0.6)\end{array}$ & n.s. \\
\hline $\begin{array}{l}\text { H' for bio-ecological diversity per station } \\
( \pm \text { s.d.) }\end{array}$ & $\begin{array}{l}1.7 \\
(0.7)\end{array}$ & $\begin{array}{l}2.4 \\
(0.2)\end{array}$ & $\begin{array}{l}2.0 \\
(0.3)\end{array}$ & $\begin{array}{l}1.7 \\
(0.6)\end{array}$ & $\begin{array}{c}2.3 \\
(0.2)\end{array}$ & $\begin{array}{c}1.6 \\
(0.4)\end{array}$ & $*$ \\
\hline
\end{tabular}

\section{Interstitial fauna}

Mean taxonomic richness

6.3

7.6

n.s.

per land-cover type ( \pm s.d.)

(2.7)

(2.7)

Number of taxa restricted to one land-cover type

8

6

Mean densities per station

( \pm s.d.)

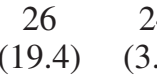

24

41

41

47

(12.3)

109

$6.0 \quad 7.3$

(43.6) (35.6)

6.0

(57.1)

Mean taxonomic richness

per station ( \pm s.d.)

(3.2) (3.0)

5.8

6.8

(1.2)

10.0

n.s.

$\mathrm{H}^{\prime}$ for taxonomic diversity per station ( \pm s.d.)

$\begin{array}{lllllll}1.8 & 2.2 & 2.1 & 2.2 & 1.9 & 2.4 & \text { n.s. }\end{array}$

(0.7) (0.5)

(0.8) (0.3)

(0.4)

(0.5)

$\mathrm{H}^{\prime}$ for bio-ecological diversity per station

( \pm s.d.)

$\begin{array}{ccccccc}0.5 & 1.2 & 1.3 & 0.9 & 1.1 & 1.4 & \text { n.s. } \\ (0.7) & (0.3) & (0.9) & (0.6) & (0.3) & (0.4) & \end{array}$


was similar to the agricultural streams (Table 2). Taxonomic richness and $\mathrm{H}^{\prime}$ diversity did not significantly change between stations.

\section{Benthic habitat and composition of the benthic fauna}

The co-inertia analysis was highly significant (Monte Carlo test, $\mathrm{P}=1.10-7$ ), with $71.27 \%$ of the total co-inertia explained on the two first axis $(51.61 \%$ for PC1 and $19.66 \%$ for PC2, respectively). Correlations between station coordinates on this plane from the PCA and the MCA were respectively 0.87 for the first axis and 0.79 for the second, which indicates a consistent relationships between faunal and environmental data.

\section{Physico-chemical characteristics}

Forested and agricultural streams were clearly separated on the first axis ( $\mathrm{PC} 1$ ) according to the environmental parameters (noted by a circle, Fig. 2C). Forested streams were characterized (Fig. 2B) by a high level of dissolved oxygen (above $10.75 \mathrm{mg} / \mathrm{L}$ ), coarse sediment (43.51 to $59.33 \%$ ), low contents in nitrite (below 0.002 mg-N/L), low nitrate ( 0.235 to $0.679 \mathrm{mg}-\mathrm{N} / \mathrm{L})$, low $\mathrm{pH}$ (6.92 on average), and low electric conductivity (125 to $145 \mu \mathrm{S} / \mathrm{cm}$ ). The agricultural streams A1 and A2 (negative side of PC1) were characterized by lower values of dissolved oxygen compared to F sites $(10.39 \mathrm{mg} / \mathrm{L}$ on average), high level of fine sediments (9.34 to $18.04 \%$ ), organic matter (more than $3 \%$ ), nitrite $(0.021$ to 0.024 $\mathrm{mg}-\mathrm{N} / \mathrm{L}$ ), nitrate (4.92 to $7.95 \mathrm{mg}-\mathrm{N} / \mathrm{L})$, phosphate ( 0.017 to $0.031 \mathrm{mg}-\mathrm{P} / \mathrm{L}$ ), and electric conductivity ( 284 to $325 \mu \mathrm{S} / \mathrm{cm}$ ). The second axis separated the A3 stream on the positive side, mainly because of a high content in fine sediment (41.6\% on average), low oxygen (9.1 to 9.2 $\mathrm{mg} / \mathrm{L}$ ) and high ammonium contents ( 0.054 to $0.062 \mathrm{mg}$ $\mathrm{N} / \mathrm{L}$ ) compared to A1 and A2 streams.

\section{Benthic fauna}

Forested and agricultural streams were also clearly separated on the $\mathrm{PC} 1$ axis according to the faunal assemblages (distal end of arrows, Fig. 2C) and the station A3 was separated on the positive side of the PC2 axis. Forested streams (positive side of PC1) were characterized by rheophilous taxa (Baetis sp. or Dupophilus brevis (Mulsant \& Rey)), organisms that live on coarse sediment (Agapetus sp.), that need well-oxygenated oligotrophic water (Leuctra gr. nigra (Olivier), Chloroperla tripunctata (Scopoli), Habroleptoides confusa Sartori \& jacob), and shredders living into leaf litter and woody debris (Habrophlebia fusca (Curtis), Tanytarsini sp.). Two samples of the station F3 (i.e. F32 and F33 on Fig.

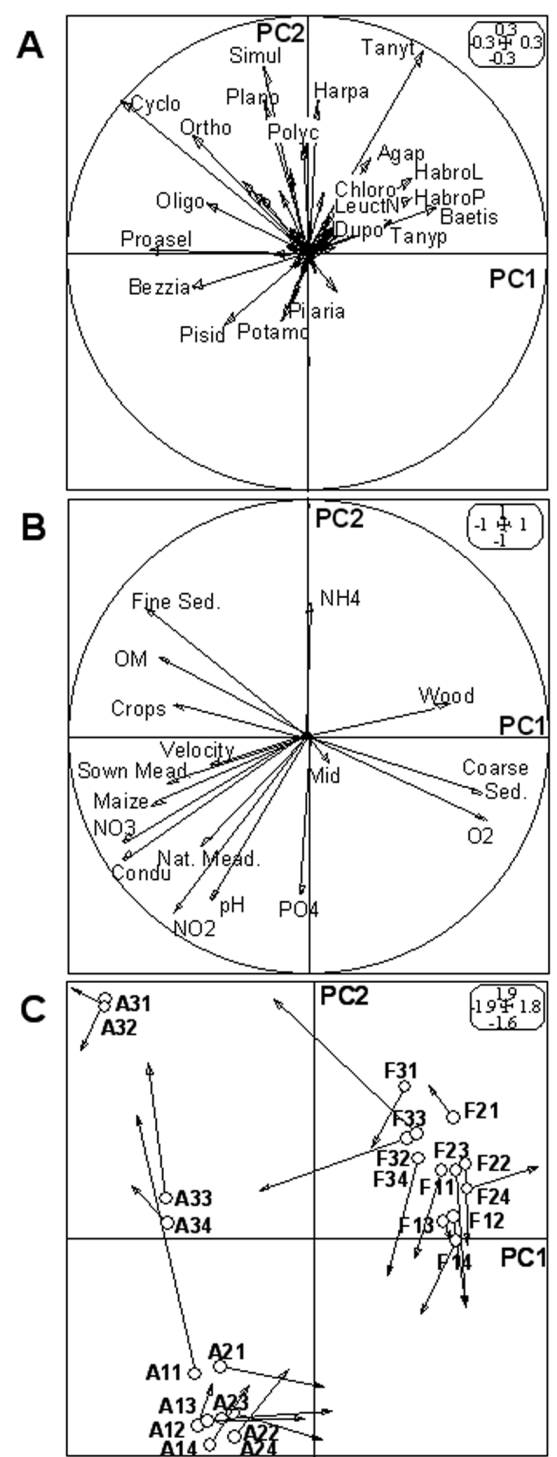

Fig. 2. Comparison of benthic samples positions on the PC1-PC2 planes by co-inertia analysis (a) ordination of species on the PC1PC2 plane (Agap: Agapetus sp., Chloro: Chloroperla tripunctata, Cyclo: Cyclopids, Dupo: Dupophilus brevis, HabroL: Habrophlebia fusca, HabroP: Habroleptoides confusa, Harpa: Harpaticids, LeuctraN: Leuctra gr. nigra, Oligo: Oligochaeta, Ortho: Orthocladiinae, Plano: Planorbarius corneus, Pisid: Pisidium sp., Polyc: Polycelis tenuis, Potamo: Potamopyrgus antipodarum, Proasel: Proasellus meridianus, Simul: Simuliini sp., Tanyp: Tanypodinae, Tanyt: Tanitarsini); (b) ordination of physico-chemical parameters on the PC1-PC2 plane (Condu: electric conductivity, Sown Maed.: sown meadows, Nat. Mead: permanent meadows, OM: organic matter, Fine Sed, Mid., Coarse Sed: grain size characteristics of bottom sediments); (c) double representation of stations on the co-inertia biplot: ring marks the location according to environmental parameters and the tip of the arrow marks the location according to invertebrate assemblages. 
2C) stand out of this group because of a high proportion of Pisidium sp., Proasellus meridianus (Racovitza), and Cyclopids, which live predominantly in slow flowing rivers with sandy sediments. Stations A1 an A2 (negative side of $\mathrm{PC} 1$ and $\mathrm{PC} 2$ ) were characterized by polysaprobic organisms that live on fine sediments or silt (Pisiduim sp., Bezzia sp.), in meso to eutrophic rivers (Hexatoma sp.), and that fed on thick periphyton (Potamopyrgus antipodarum (Smith)). Finally, the station A3 was characterized by organisms that live on fine sediments (Oligochaeta, Harpacticids, and Orthocladinae), in lentic water (Cyclopids, Polycelis tenuis Ijima, Planorbarius corneus L.), and by a high density of Simuliidae due to the important development of vegetation in this station.

\section{Vegetation habitat and composition of the fauna}

The co-inertia analysis was highly significant (Monte Carlo test, $P=1.10^{-7}$ ), with $62.68 \%$ of the total co-inertia explained on the two first axis (respectively $45.49 \%$ for PC1 and $17.19 \%$ for PC2). Correlations between station coordinates on this plane from the PCA and the MCA were respectively 0.91 for the first axis and 0.86 for the second, which indicates a consistent relationships between faunal and environmental data

\section{Physico-chemical characteristics}

Forested and agricultural streams were clearly differentiated on the $\mathrm{PC} 1$ axis (Fig. 3C) according to their environmental characteristics (Fig. 3B): forested streams with high level of dissolved oxygen, low nitrite and nitrate contents, low $\mathrm{pH}$ and electric conductivity. The vegetation differed between the streams F1 and F2 (with moss or woody debris) and the stream F3 dominated by aquatic macrophytes (positive side of PC2). On the negative side of the $\mathrm{PC} 1$ axis, agricultural streams were characterized by higher nutrient and lower dissolved oxygen contents than in forested streams. Stations A1 and A2 were characterized by high phosphorus content and plant debris, while station $\mathrm{A} 3$ (positive side of $\mathrm{PC} 2$ ) harboured a high density of herbaceous (semi-aquatic) vegetation.

\section{Fauna of the vegetation}

Forested streams (positive side of PC1, Fig. 3C) were characterized by oligotrophic and oligosaprobic or even xenosaprobic organisms (Plectronemia sp., Leuctra gr. fusca L., Leuctra gr. nigra, Wormaldia sp. or the Ostracoda Cryptocandona vavrai Kaufmann). The F1 and F2 streams (negative on PC2 axis) were characterized by shredders that live preferentially on moss or woody debris (Habrophlebia fusca or the Limnephilinae), by predators that live in branches or roots (Calopteryx virgo)

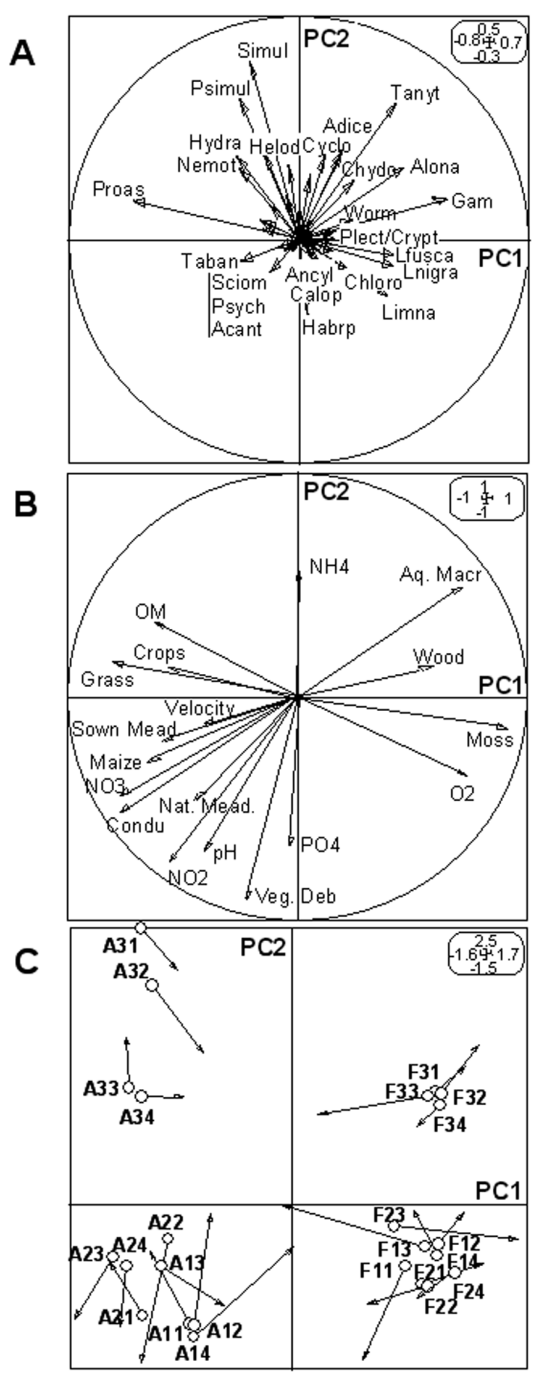

Fig. 3. Comparison of vegetation samples positions on two PC1PC2 planes by co-inertia analysis (a) ordination of species on the PC1-PC2 plane (Acant: Acanthocnema sp., Adice: Adicela sp., Alona: Alona quadrangularis, Ancyl: Ancylus fluviatilis, Calop: Calopteryx virgo, Chloro: Chloroperla tripunctata, Chydo: Chydorus sphaericus, Crypto: Cryptocandona vavrai, Cyclo: Cyclopids, Gam: Gammarus pulex, HabroP: Habroleptoides confusa, Helod: Helodes sp., LeuctraF: Leuctra gr. fusca, LeuctraN: Leuctra gr. nigra, Limna: Limnephilinae, Nemot: Nemotaulius punctatolineatus, Plect: Plectrocnemia sp., Proasel: Proasellus meridianus, Psimul: Prosimuliini sp., Psych: Psychodidae, Sciom: Sciomizidae, Simul: Simuliini sp., Taban: tabanidae, Tanyt: Tanitarsini, Worm: Wormaldia sp.); (b) ordination of physico-chemical parameters on the PC1-PC2 plane (Condu: electric conductivity, Sown Maed.: sown meadows, Nat. Mead: permanent meadows, OM: organic matter, Aquat. Macr: aquatic macrophytes, Veg. Deb: vegetation debris); (c) double representation of stations on the co-inertia biplot: ring marks the location according to environmental parameters and the tip of the arrow marks the location according to invertebrate assemblages. 
and by rheophilous organisms that need well-oxygenated water (Chloroperla tripunctata or Ancylus fluviatilis (Müller)). In contrast, the stream F3 (positive side of PC2) harboured phytophilous species (Adicela sp. or Tanytarsini sp.) or organisms living in slow flowing waters (Cyclopids, Alona quadrangularis (Müller), Chydorus sphaericus (Müller)). Agricultural streams were characterized by polysaprobic organisms living in meso-to eutrophic lentic water (Proasellus meridianus, Hydra sp.). The streams A1 and A2 (negative on both axes) harboured polysaprobic organisms that live on plant debris (Acanthocnema sp.) and that prefer slow flowing or stagnant water (Sciomizidae, Psychodidae, Tabanidae). Finally, stream A3 was characterized by organisms preferring lentic water and feeding on coarse organic matter (Nemotaulius punctatolineatus (Retzius)) or that fed on drifting material (bacteria or living microphytes) such as Simuliini sp. and Prosimuliini sp.

\section{Interstitial habitat and composition of the fauna}

The co-inertia analysis was highly significant (Monte Carlo test, $P=1.10^{-7}$ ), with $70 \%$ of the total co-inertia explained by the first two axes (respectively $59.18 \%$ for F1 and $10.82 \%$ for F2). Correlations between station coordinates on this plane from the PCA and the MCA were respectively 0.85 for the first axis and 0.73 for the second, which indicates a consistent relationships between faunal and environmental data.

\section{Physico-chemical characteristics}

Forested and agricultural streams were clearly separated on the $\mathrm{PC} 1$ axis (Fig. 4C) according to their environmental characteristics (Fig. 4B): forested streams were with intermediate values of dissolved oxygen (3.6 $\mathrm{mg} / \mathrm{L}$ on average), low electric conductivity (between 149 to $165 \mu \mathrm{S} / \mathrm{cm}$ ), and low nitrate ( 0.03 to $0.48 \mathrm{mg}-\mathrm{N} / \mathrm{L}$ ). Agricultural streams were located on the negative side of the $\mathrm{F} 1$ axis, because of high levels of nitrate (2.26 to 8.02 mg-N/L), high electric conductivity (307 to $327 \mu \mathrm{S} / \mathrm{cm}$ ), and low dissolved oxygen contents (always below $2 \mathrm{mg}$ / L). A gradient can be observed in the agricultural streams mostly due to an increase in ammonium, nitrite, and phosphate contents from A1 to A3.

\section{Interstitial fauna}

The agricultural and forested streams were poorly differentiated on the co-inertia plane (Fig. 4C). Forested streams were roughly located on the positive side of the PC1 axis and were characterized by organisms that need well oxygenated oligotrophic water (Leuctra gr. fusca, Paraleptophlebia submarginata (Stephens), Leptophle-

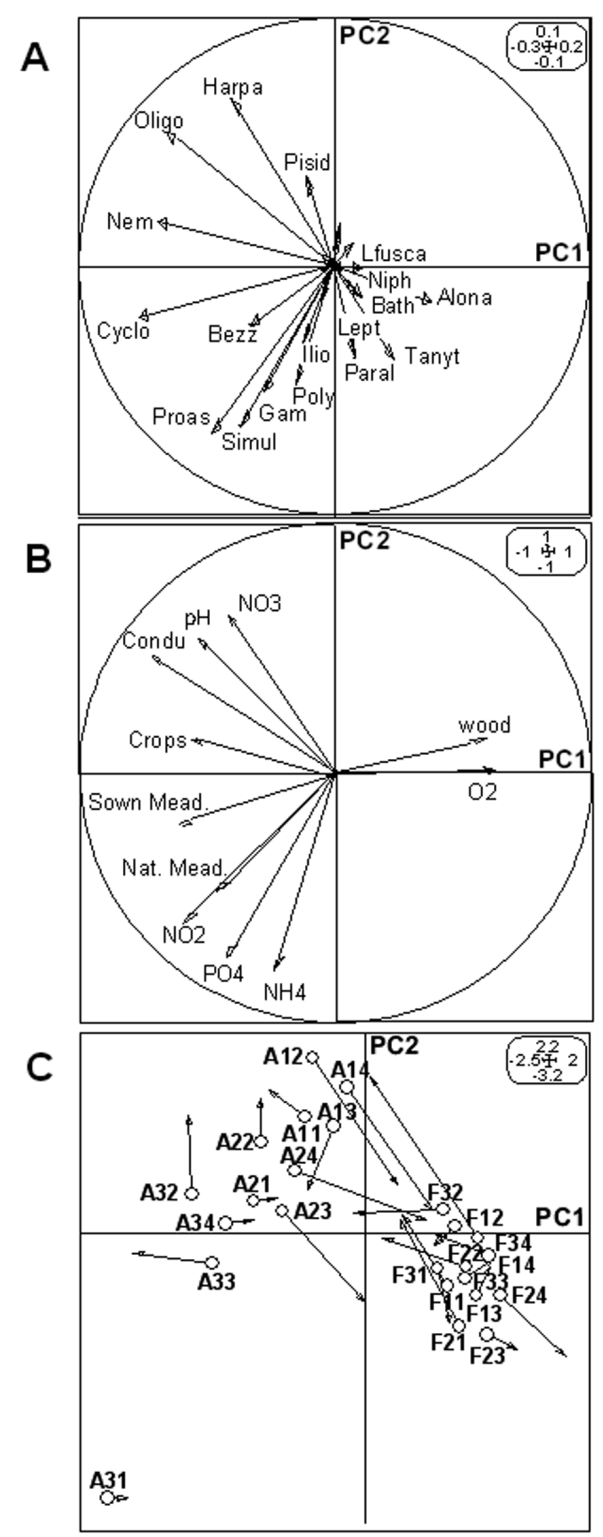

Fig. 4. Comparison of interstitial samples positions on the PC1-PC2 planes by co-inertia analysis (a) ordination of species on the PC1PC2 plane (Alona: Alona quadrangularis, Bath: Bathynellidae, Cyclo: Cyclopids, Harpa: Harpaticids, Iloi: Iliocryptus sordidus, Lept: Leptophlebia marginata, LeuctraF: Leuctra gr. fusca, Nem: Nematoda, Niph: Niphargus aquilex, Oligo: Oligochaeta, Paral: Paraleptophlebia submarginata, Pisid: Pisidium sp., Poly: Polycelis tenuis, Proasel: Proasellus meridianus, Simul: Simuliini sp., Tanyt: Tanitarsini); (b) ordination of physico-chemical parameters on the PC1-PC2 plan (Condu: electric conductivity, Sown Maed.: sown meadows, Nat. Mead: permanent meadows); (c) double representation of stations on the co-inertia biplot: ring marks the location according to environmental parameters and the tip of the arrow marks the location according to invertebrate assemblages. 
bia marginata L.) and strong exchanges with surface water (Tanytarsini, Alona quadrangularis) or with groundwater (Niphargus aquilex, Bathynellidae). These faunal characteristics decreased from stations F2 (where Bathynellidae was sampled) to stations F3 (dominated Nematoda and Harpacticoida). Agricultural streams are located on the negative side of the PC1 axis and were characterized by organisms that live preferentially in fine sediment or silt (Pisiduim sp., Harpacticoida, Nematoda, Oligochaeta) and in meso to eutrophic water (Proasellus meridianus). Station A3 have the most negative coordinates on the $\mathrm{PC} 1$ and $\mathrm{PC} 2$ axes because of a combination of organisms that live in sandy organic sediment (Bezzia sp., Iliocryptus sordidus (Lievin), Proasellus meridianus and Cyclopids) together with organisms generally restricted to surface water (Simuliini sp., Gammarus pulex L. and Polycelis tenuis).

\section{Species traits}

In the benthic layer, the six groups showed a relevant trend according to catchment land-cover (Fig. 5). In forested streams, the relative taxonomic richness of the $\alpha 2$, $\beta$ and $\gamma 1$ groups were significantly higher than in agricultural streams. In contrast, agricultural streams hosted significantly more meso- to polysaprobic organisms of $\gamma 2$ and $\delta 2$ groups compared to the F1 and F2 streams. The relative taxonomic richness of the $\zeta$ group was the highest in the stream $\mathrm{A} 1$ and the weakest in the streams F1 and F2. The assemblage of the disturbed stream F3 was similar to those of the agricultural streams, with significantly more polysaprobic species ranged in group $\delta 2$ and a fewer proportion of organisms of the groups $\beta$ and $\gamma 1$.

For the fauna of the vegetation, only four groups showed relevant and significant differences between agricultural and forested streams (Fig. 6). There was a higher proportion of taxa of the $\gamma 1$ group in forested streams, while poor differences were observed in the $\gamma 2$ group. The abundance of the $\alpha 2$ and $\beta$ groups significantly differed between the forested stream F1 and the agricultural streams A3 and A1, while the other streams were in an intermediate position.

Most of the interstitial organisms belonged to the group $\zeta$ (between $20 \%$ and $60 \%$, Fig. 7), thus little difference was observed between forested and agricultural streams. Streams A 2 and A 3 showed a higher proportion of the $\gamma 2$ group, which lacked completely in the F1 stream.

Finally, H' diversities calculated with bio-ecological traits (Table 2) were significantly higher in the forested than in the agricultural streams when the benthic fauna was considered, varied between station in the vegetation (but without relevant trend with the land-cover or the level of disturbance), and did not significantly change in the interstitial habitat.

\section{Discussion}

\section{Changes in water chemistry and sediment characteristics}

Human activities modified both water and sediment characteristics, even in the forested streams. A patchy disturbance linked to road construction (stream F2) did not significantly modify water characteristics, while a disturbance at the catchment-scale (wind-fallen wood area around the stream F3) changed the stream characteristics, with a great development of aquatic vegetation and an increase in organic matter and fine sediments contents. Similar effects were documented for fine sediments inputs (Benfield et al. 2001) and expansion of aquatic vegetation (Madsen \& Adams 1989), they are more drastic in pristine forests (Webster \& Waide 1982, Dobson \& Cariss 1999), which is not the case in our study area.

Agriculture induced strong increases in nitrate content in stream water (ten times higher than in forested streams), because of the massive use of minerals and organic fertilizers for maize or other cereal cultures surrounding the streams (Liess et al. 1999, Domburg et al. 2000, Haggard et al. 2001). The reduction of riparian vegetation and wetland certainly reduced the biotic uptake and denitrification in the river margin (Grimaldi \& Chaplot 1999, Martin et al., 2004). These changes increased with agriculture intensity: streams A1 and A2 had similar water characteristics, while the disturbance of the A 3 stream (intensive agriculture and the direct access of cows to the channel) resulted in a strong decrease in water and sediment qualities. The increase in field size (Whiles et al., 2000), the reduction of hedgerow network (Cuffney et al. 2000) and cow trampling (Crespin de Billy et al. 2000) may explain the increase in fine sediment content observed in stream A3, where partial clogging of interstitial habitat induced ammonium accumulation that sometimes reached the threshold of toxicity for organisms (over $0.2 \mathrm{mg}-\mathrm{N} / \mathrm{L}$ for Salmonidae embryos, Massa2000). Ammonium accumulation in the river interstices is the result of an oxygen depletion and a stop of the nitrification process (Dahm et al. 1987, Hedin et al. 1998, Soulsby et al. 2001, Lefebvre et al. 2004, 2006).

\section{Fauna composition and stream characteristics}

The modifications of the land-cover at the catchment scale and the resulting changes at the habitat scale mod- 

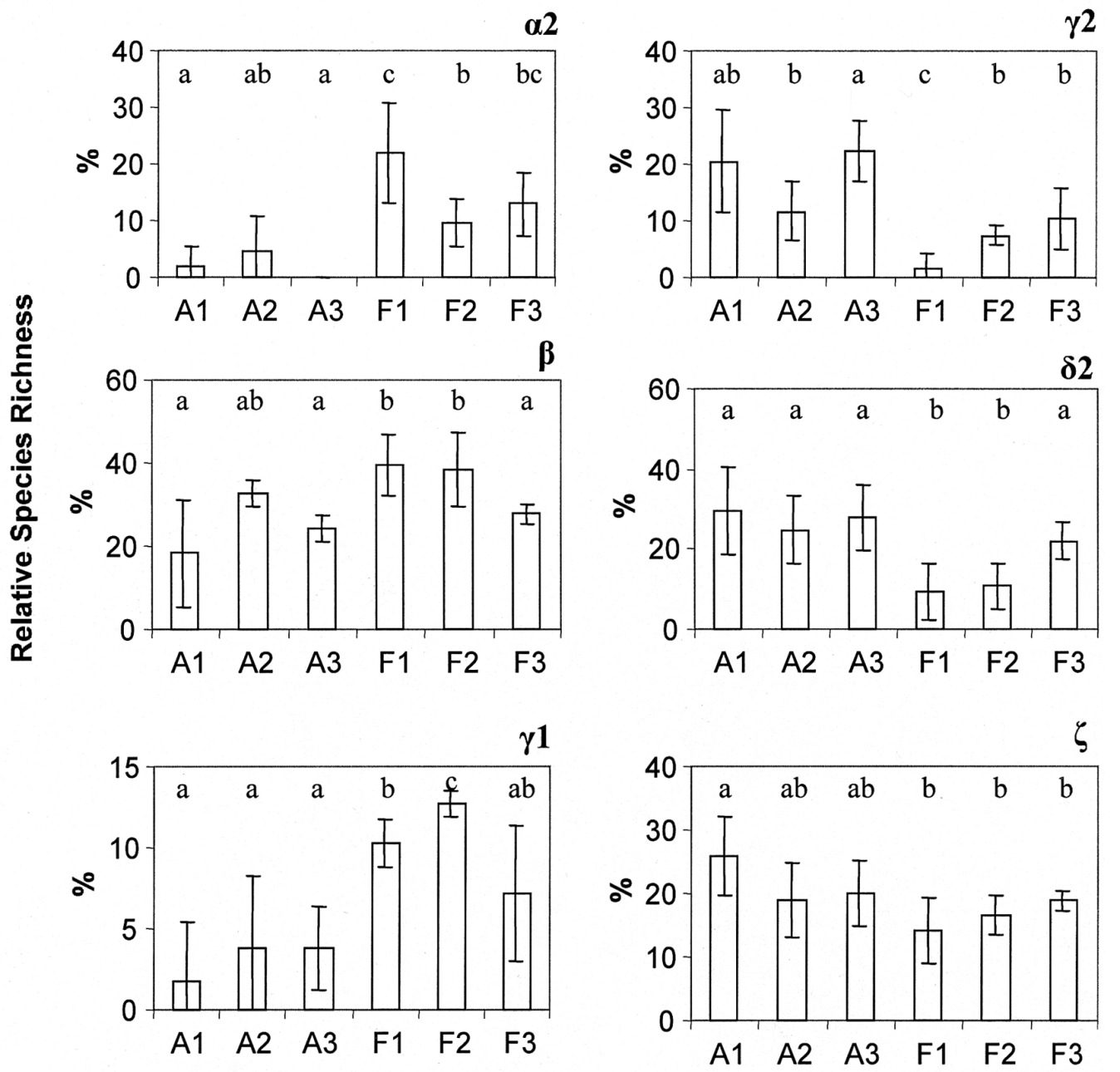

Fig. 5. Mean taxonomic richness of the six bio-ecological groups $(\alpha 2, \beta, \gamma 1, \gamma 2, \delta 2$ and $\zeta)$ for the benthic fauna of the six studied streams. Mean richness $( \pm$ SE) calculated with the 4 replicate samples, streams noted with the same letter are not significantly different (ANOVA test).

ified the structure and the composition of invertebrate assemblages. In the forest streams, the patchy disturbance of the forest around stream F2 (road construction) did not modify aquatic fauna. Sidle et al. (2004) reported changes in the invertebrate assemblages due to the roads used during logging, certainly because they were built in pristine catchments. In the studied area, the forest has been disturbed by logging since the middle age.

The tree fall around the stream F3 induced changes in the invertebrate assemblages that became more similar to those sampled in an agricultural stream, with increase of densities in both the benthic layer and the aquatic vegetation. This is particularly true for the fauna of the vegetation, certainly because of the increase in the available space for phytophilous organisms and habitat heterogene- ity (compared to dead leaves and woody debris), that plays a key role for aquatic invertebrates (Cellot et al. 1994, Beisel et al. 1998, 2000, Clarke et al. 2003). Tree fall also increases the light availability and the biomass of benthic algae (major food source for several invertebrates, Robinson \& Minshall 1986). Stone and Wallace (1998) observed that after tree fall autochthonous production of organic matter can exceed allochthonous inputs, with strong changes in the invertebrates assemblages.

With changes in land-cover, we noticed the decrease of organisms that prefer coarse sediments and well oxygenated oligotrophic water (present in forested streams) in favour of animals living in fine organic sediment or macrophytes and that tolerate eutrophication (dominant in the three agricultural streams). Modifications of aquatic 

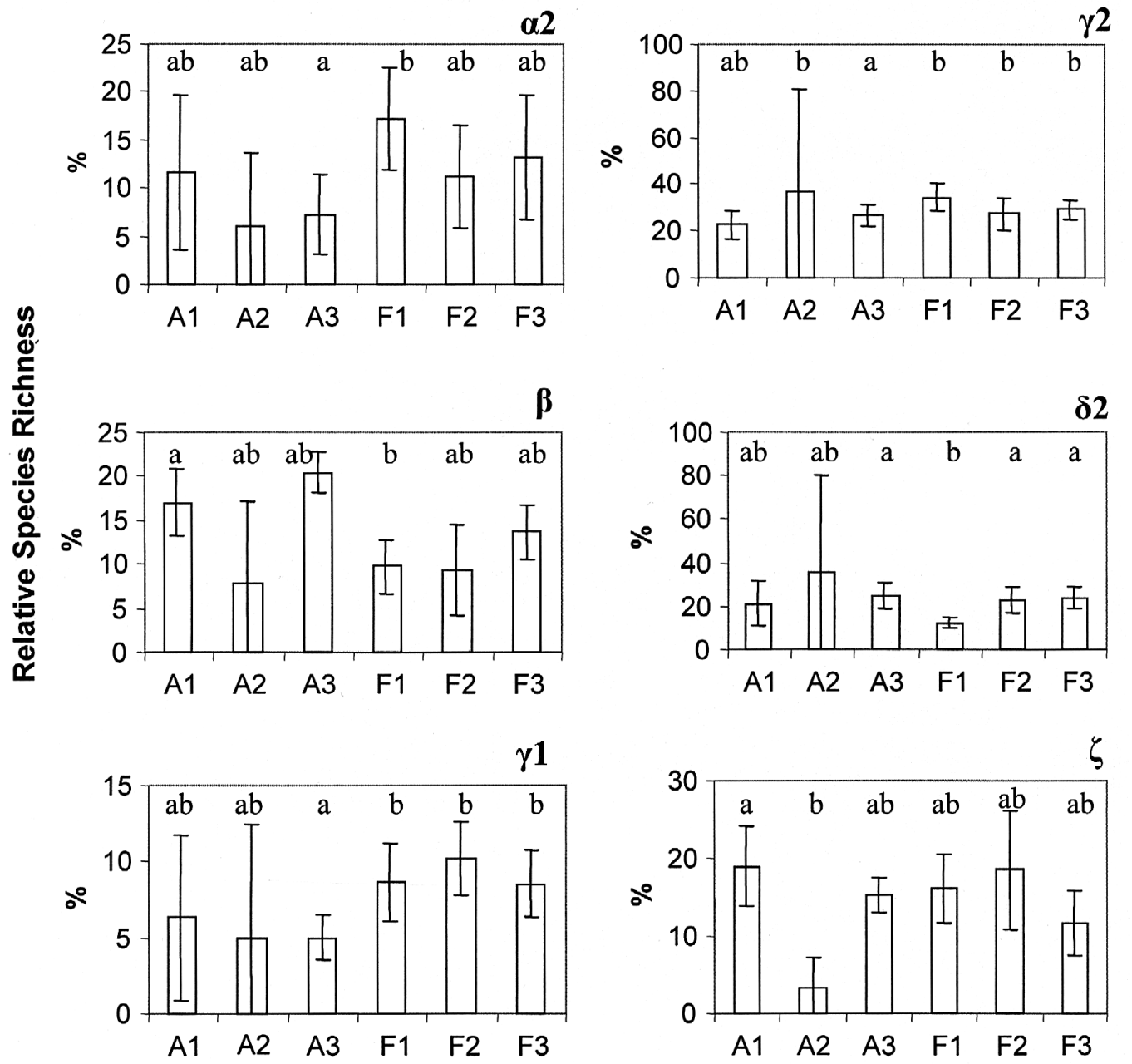

Fig. 6. Mean taxonomic richness of the six bio-ecological groups $(\alpha 2, \beta, \gamma 1, \gamma 2, \delta 2$ and $\zeta)$ for the fauna of the vegetation. Mean richness $( \pm$ SE) calculated with the 4 replicate samples, streams noted with the same letter are not significantly different (ANOVA test).

communities with changes in land-cover (Townsend et al. 1997) were linked to the accumulation of fine sediment and organic matter resulting from soil erosion (Culp et al. 1983, Rempel et al. 2000), the stimulation of micro and macrophyte growth (Madsen \& Adams 1989), with increase in phytophilous organisms (Jenkins et al. 1984, Rutt et al. 1989). In our study, the changes in aquatic fauna were more pronounced with increasing agriculture intensity, but with an unexpected pattern. Catchment scale disturbance, like reduction in hedgerow networks in stream A2, did not impact significantly the stream fauna that remained very similar in stations A1 and A2. In contrast, a disturbance of the interface between the river and the catchment (direct access of the cattle to the river in station A3) induced strong modifications in the fauna of the three studied habitats.

\section{Habitat-specific response to disturbance}

The effects of catchment disturbance on invertebrate assemblages were not similar in the three studied habitats, with increasing differences between assemblages from the interstitial, to the benthic, and to the vegetation fauna. There was a clear link between stream characteristics and invertebrate assemblages in the vegetation, with consistent differences between agricultural and forested streams, between the stream F3 and the two other forested streams, and between the stream $\mathrm{A} 3$ and the two other agricultural streams. The benthic fauna clearly differed between forested and agricultural streams, but the fauna of the stream F3 did not show any specific composition compared to the streams F1 andF2. Finally, the link between land-cover and interstitial fauna was poorly 

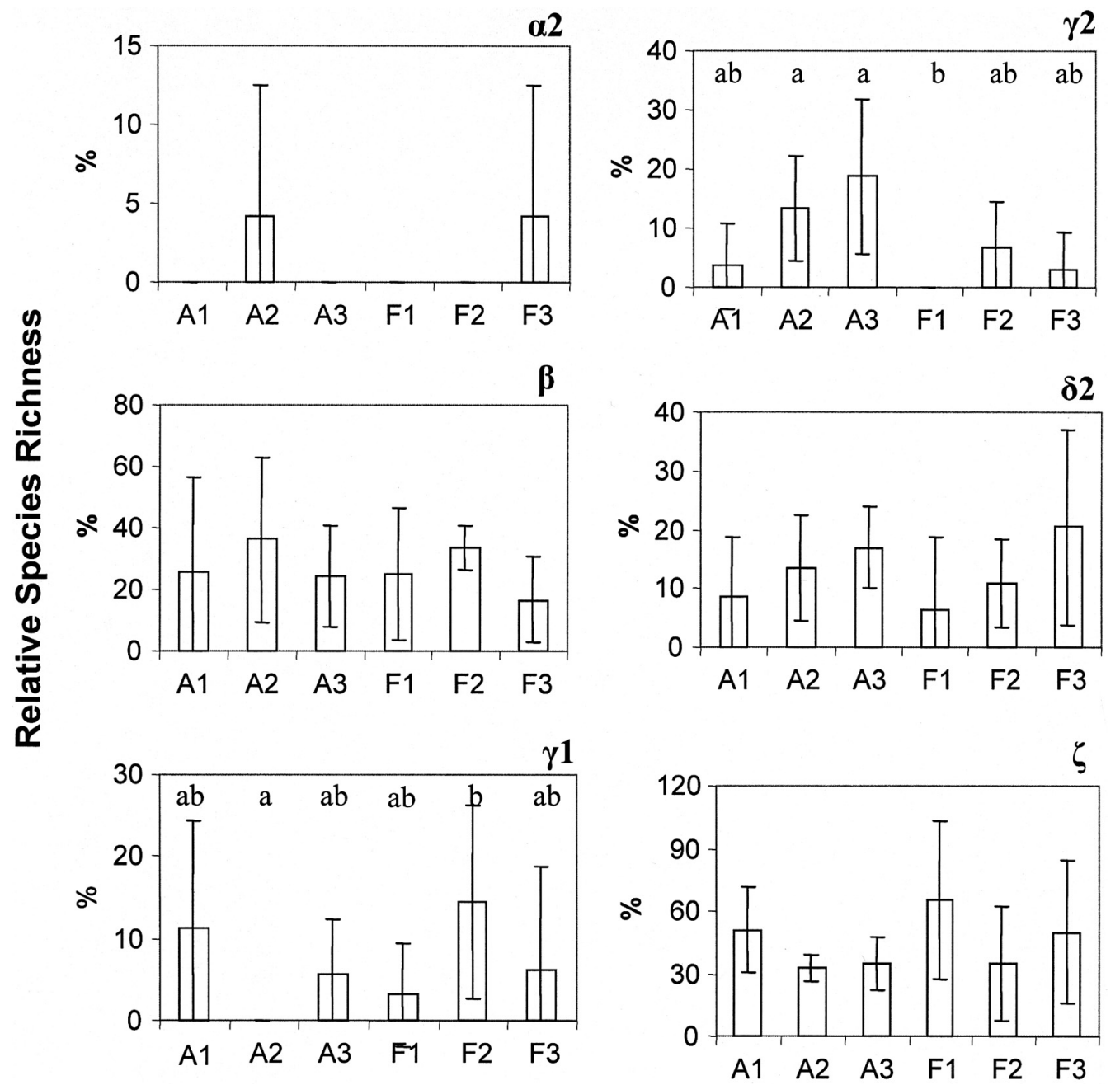

Fig. 7. Mean taxonomic richness of the six bio-ecological groups $(\alpha 2, \beta, \gamma 1, \gamma 2, \delta 2$ and $\zeta)$ for the interstitial fauna of the six studied streams.

Mean richness $( \pm$ SE) calculated with the 4 replicate samples, streams noted with the same letter are not significantly different (ANOVA test).

supported by the results. The only significant difference in the interstitial assemblages was observed in the A3 stream, where the highest changes in sediment characteristics were observed.

This poor link may be due to low density and abundance of hyporheic organisms. At $20 \mathrm{~cm}$ deep inside sandy sediment, the low dissolved oxygen content can limit the colonization by macro- and meiofauna (Schmid-Araya 2000) and the survival of epigean animals in the interstitial habitat (Strayer et al. 1997, Marmonier et al. 1999). A second reason for this poor link may be the limited level of identification for most dominant organisms (Nematoda, Oligochaeta, Copepods, Chironomidae) that can be an important limiting factor for the relevance of our results. This problem is widely recognized in the literature, but remains very controversial: some authors defend an identification at the species level (Lenat \& Resh 2001, King \& Richardson 2002), while others support that the genus or the family resolution could suffice (Wright et al. 1995, Boulton et al. 2004). A third explanation may be the resistance of the dominant taxa to disturbances: several species of Nematoda and Oligochaeta are known to resist to decrease in water quality and to fine sediment increase (e.g. Townsend et al. 1997).

\section{Changes in bio-ecological groups}

We observed significant differences along the gradient of disturbance for the relative taxonomic richness and the 
diversity of groups based on bio-ecological traits of organisms (Usseglio-Polatera et al. 2001), but decreasing from the benthic, to the vegetation, and to the interstitial habitat. In the benthic layer, diversities were weaker in agricultural than in forested streams and the taxonomic richness of all groups significantly changed between stations (with four groups showing higher or weaker richness in F1 and F2 than in agricultural streams). In the vegetation, diversities changed between stations but without trends according to land-cover and the relative species richness poorly changed (two groups) between agricultural and the forested streams F1 and F2. Finally, diversities in the interstitial habitat did not change between stations and no trend according to land-cover was observed in relative taxonomic richness of bio-ecological groups.

The effects of human activities on the combination of biological and ecological traits in the assemblages were already observed in many different contexts (e.g. between different catchments, Usseglio-Polatera et al. 1999, or upstream-downstream of an organic pollution, Usseglio-Polatera et al. 2000), but always in the surface assemblages. In this study, we used this approach for interstitial fauna with poor results, certainly because major constraints that shape interstitial assemblages (e.g. need for oxygen, ability for vertical migrations inside sediment) are poorly documented in the literature and not included in the traits considered by UsseglioPolatera et al. (2001). Claret et al. (1999) proposed groups for interstitial organisms based on biological traits of species and affinities to groundwater systems (i.e. stygoxene, stygophile, and stygobite). The extremely poor diversity of stygobite (hypogean) species in the sandy rivers of Brittany makes this classification poorly relevant for our study. Specific studies focussed on interstitial fauna are needed to propose efficient bioecological groups in biogeographical regions poor in stygobite species.

\section{Acknowledgements}

We thank Mrs S. Baudry for the corrections of the English, Mrs M. P. Briand and N. Josselin for the laboratory analyses and Mr D. Butet, M. Guillevic and E. Helard for their technical assistance in the field. This study was funded by grants from the French Ministry of "Ecology and Sustainable Development" (Grant N $\left.{ }^{\circ} 5000346\right)$.

\section{References}

Allan D.J. \& Johnson L.B. 1997. - Catchment-scale analysis of aquatic ecosystems. Freshwat. Biol., 37, 107-111.

Arheimer B. \& Liden R. 2000. - Nitrogen and phosphorous concentrations from agricultural catchments - influence of spatial and temporal variables. J. Hydrol., 227, 140-159.

Barnes H. \& Kollard A.R. 1951. - The determination of nitrite. National Council for Exploration of the Sea, Charlotteland.
Beisel J.N., Usseglio-Polatera P. \& Moreteau J.-C. 2000. - The spatial heterogeneity of a river bottom : a key factor determining macroinvertebrate communities. Hydrobiologia, 422, 163-171.

Beisel J.N. Usseglio-Polatera P., Thomas S. \& Moreteau J.-C. 1998. - Stream community structure in relation to spatial variation: the influence of mesohabitat characteristics. Hydrobiologia, 389, 73 88.

Benfield E.F., Webster J.R., Tank J.L. \& Hutchens J.J. 2001. - Longterm patterns in leaf breakdown in streams in response to watershed logging. Internat. Rev. Gesamt. Hydrobiol., 86, 467474.

Boulton A.J. 1993. - Stream ecology and surface-hyporheic hydrologic exchange : implications, techniques and limitations. Aust. J. Mar. Freshwat. Res., 44, 553-564.

Boulton A.J., Findlay S., Marmonier P., Stanley E.H. \& Valett M.H. 1998. - The functional significance of the hyporheic zone in streams and rivers. Ann. Rev. Ecol. Syst., 29, 59-81.

Boulton A., Dole-Olivier M.J. \& Marmonier P. 2004. - Effects of sample volume and taxonomic resolution on assessment of hyporheic assemblage composition sampled using a Bou-Rouch pump. Arch. Hydrobiol., 159, 327-355.

Bretschko G. \& Leichtfried M. 1987. - The determination of organic mater in river sediments. Arch. Hydrobiol., 68, 403-417.

Burel F., Butet A., Delettre Y. R. \& Millan de la Pena N. 2003. Differential response of selected taxa to landscape context and agricultural intensification. Landscape Urban Plan., 1018, 1-10.

Cellot B., Dole-olivier M-J., Bornette G. \& Pautou G. 1994. Temporal and spatial environmental variability in the Upper Rhône River and its floodplain. Freshwat. Biol., 31, 311-326.

Charvet S., Statzner B., Usseglio-polatera P. \& Dumont B. 2000. Traits of benthic macro-invertebrates in semi-natural French streams: an initial application to biomonitoring in Europe. Freshwat. Biol., 43, 277-296.

Claret C. Marmonier P., Dole-Olivier M.-J., Creuze des Châtelliers M., Boulton A.J. \& Castella E. 1999. - A functional classification of interstitial invertebrates: supplementing measures of biodiversity using species traits and habitat affinities. Arch. Hydrobiol., 145, 385-403.

Clarke S. J., Bruce-Burgess L. \& Wharton G. 2003. - Linking form and function: towards an eco-hydromorphic approach to sustainable river restoration. Aquatic. Conserv. Mar. Freshw. Ecosyst., 13, 439-450.

Collier K.J. \& Smith B.J. 2005. - Effects of progressive catchment harvesting on stream invertebrates in two contrasting regions of New Zealand's North Island. New Zeal. Mar. Fresh. Res., 56, 5768.

Crespin de Billy V., Reyes-Marchant P., Lair N. \& Valadas B. 2000. - Impact of agricultural practices on a small headwater stream: terrestrial and aquatic characteristics and self-purifying processes. Hydrobiologia, 421, 129-139.

Cuffney T. F., Meador M. R., Porter S. D. \& Gurtz M. D. 2000. Responses of physical, chemical and biological indicators of water quality to a gradient of agricultural land use in the Yakima river basin, Washington. Environ. Monit. Asses., 64, 259-270.

Culp J. M., Walde S. J. \& Davies R. W. 1983. - Relative importance of substrate particle size and detritus to stream benthic macroinvertebrate microdistribution. Can. J. Fish. Aquat. Sci., 40, 1568-1574.

Dahm C. N., Grimm N. B., Marmonier P., Valet M. H. \& Vernier P. 1998. - Nutrient dynamics at the interface between surface waters and groundwater. Freshwat. Biol., 40, 427-451.

Dahm C. N., Trotter E. H. \& Sedell J. R. 1987. - Role of anaerobic zones and processes in stream ecosystem productivity. Pages 157- 
178 in Chemical Quality of Water and the Hydrological Cycle. Averett R. C. \& McKnight D. M. (eds). Chelsea, Michigan.

Dobson M. \& Cariss H. 1999. - Restoration of afforested upland streams - what are we trying to achieve? Aquat. Conserv. Mar. Freshwat. Ecosyst., 9, 133-139.

Doledec S. \& Chessel D. 1994. - Co-inertia analysis: an alternative method for studying species-environment relationships. Freshwat. Biol., 31, 277-294.

Domburg P., Edwards A. C., Sinclair A. H. \& Chalmers N. A. 2000. - Assessing nitrogen and phosphorus efficiency at farm and catchment scale using nutrient budgets. J. Sc. Food Agr., 80, 1946-1952.

Gregel S.E., Turner M.G., Miller J.R., Melack J.M. \& Stanley E.H. 2002. - Landscape indicators of human impacts to riverine systems. Aquat. Sci., 64, 118-128.

Grimaldi C. \& Chapelot V. 2000. - Nitrate depletion during withinstteam transport: effects of exchange processes between streamwater, the hyporheic zone and riparian zones. Water Air Soil Poll., 124, 95-112.

Gulis V. \& Suberkropp K. 2003. - Leaf litter decomposition and microbial activity in nutrient-enriched and unaltered reaches of headwater stream. Freshwat. Biol., 48, 123-134.

Habdija I., Radanovic I., Primc-habdija B. \& Spoljar M. 2002. Vegetation cover and substrate type as factors influencing the spatial distrubution of Trichopterans along a karstic river. Int. Rev. Gesamt. Hydrobiol., 87, 423-437.

Haggard B.E., Storm D.E., Terjral R.D., Popova Y.A., Keyworth V.G. \& Stanley E.H. 2001. - Stream nutrient retention in three northeastern Oklahoma agricultural catchments. Am. Soc. Agri. Eng., 44, 597-605.

Hancock P. 2002. - Human impacts on the stream-groundwater exchange zone. Environ. Manag., 29, 763-781.

Harding J.S., Benfield E.F., Bolstad P.V., Helfman G.S. \& Jones E.B.D. 1998. - Stream biodiversity: the ghost of land use past. Proc. Natl. Acad. Sci. USA, 95, 14843-14847.

Hedin L.O., Fischer J.C., Ostrom N.E., Kenedy B.P., Brown M.G. \& Robertson G.P. 1998. - Thermodynamic constraints on nitrogen transformations and other biogeochemical processes at soilstream interfaces. Ecology, 79, 684-703.

Jenkins R.A., Wase K.R. \& Ough E. 1984. - Macroinvertebratehabitat relationships in the River Teine catchment and the significance to conservation. Freshwat. Biol., 14, 23-42.Hunsaker C.T. \& Levine D.A. 1995. - Hierarchical approaches to the study of water quality in rivers. BioScience, 45, 193-203.

King R.S. \& Richardson C.J. 2002. - Evaluating subsampling approaches and macroinvertebrate taxonomic resolution for wetland bioassessment. J. N. Am. Benthol. Soc., 21, 150-171.

Lefebvre S., Marmonier P. \& Pinay G. 2004. - Stream regulation and nitrogen dynamics in sediment interstices: comparison of natural and straightened sectors of a third order stream. River Res. Appl., 20, 499-512.

Lefebvre S., Marmonier P. \& Peiry J.-L. 2006 - Nitrogen dynamics in rural streams: differences between geomorphologic units. Ann. Limnol. - Int. J. Limnol., 42, 43-52.

Lenat D. R. \& Resh J. K. 2001. - Taxonomy and stream ecologyThe benefits of genius- and species-level identifications. J. N. Am. Benthol. Soc., 20, 287-298.

Liess M., Schultz R., Liess M.H.D., Rother B. \& Kreuzig R. 1999. Determination of insecticide contamination in agricultural headwater streams. Water Res., 33, 239-247.

Madsen J.D. \& Adams M.S. 1989. - The distribution of submerged aquatic macrophyte biomass in an eutrophic stream, Badfish creek: the effect of environment. Hydrobiologia, 171, 111-119.
Marmonier P., Claret C. \& Dole-Olivier M-J. 1999. - Interstitial fauna in newly-created floodplain canals of a large regulated river. Reg. Rivers, Res. Manag., 16, 23-36.

Martin C., Aquilina L., Gascuel-Odoux C., Molenat J., Faucheux M. \& Ruiz L. 2004. - Seasonal and interannual variations of nitrate and chloride in stream waters related to spatial and temporal patterns of groundwater concentrations in agricultural catchments. Hydrol. Process., 18, 1237-1254.

Massa F. 2000. - Sédiments, physico-chimie du compartiment interstitiel et développement embryo-larvaire de la truite commune (Salmo trutta) : Etude en milieu naturel anthropisé et en conditions controlées. PhD Thesis, INA-PG, Paris, 179 p.

McKie B. \& Cranston P.S. 2001. - Colonisation of experimentally immersed wood in south eastern Australia : responses of feeding groups to changes in riparian vegetation. Hydrobiologia, 452, 114.

Meeus J.H.A. 1993. - The transformation of agricultural landscapes in western Europe. Sci. Total Environ., 129, 171-190.

Mulholland P.J., Elwood J.W., Newbold J.D., Webster J.R., Ferren L.A. \& Perkins R.E. 1984. - Phosphorus uptake by decomposing leaf detritus: effects of microbial biomass and activity. Verh. Internat. Verein. Limnol., 22, 1899-1905.

Murphy J. \& Riley J.P. 1975. - A modified single-solution for the determination of phosphate in natural waters. Anal. Chim. Acta, 27, 31-36

Quinn J.M. \& Stroud M.J. 2002. - Water quality and sediment and nutrient export from New Zealand hill-land catchments of contrasting land use. New Zeal. J. Mar. Fresh. Res., 36, 409-429.

Quinn J.M., Davies-Colley R.J., Hickey C.W., Vickers M.L. \& Ryan P.A. 1992. - Effects of clay discharges on streams. Hydrobiologia, 248, 235-247.

Rempel L.L., Richardson J.S. \& Healey M.C. 2000. Macroinvertebrate community structure along gradients of hydraulic and sedimentary conditions in large gravel-bed river. Freshwat. Biol., 45, 57-73.

Richards C., Haro R.J., Johnson L.B. \& Host G.E. 1997. Catchment and reach-scale properties as indicators of macroinvertebrate species traits. Freshwat. Biol., 37, 219-230.

Robinson C.T. \& Minshall G.W. 1986. - Effects of disturbance frequency on stream benthic community structure in relation to canopy cover and season. J. N. Am. Benthol. Soc., 5, 237-248.

Rossum J.R. \& Villaruz P.A. 1963. - Determination of ammonia by the indophenol method. S. Amer. Water Works Ass., 55, 657.

Rutt G.P., Weatherly N.S. \& Ormerod S.J. 1989. - Microhabitat availability in Welsh moorland and forest streams as a determinant of macroinvertebrate distribution. Freshwat. Biol., 22, 247-261.

Schmid-Araya, J.M. 2000. - Invertebrate recolonization patterns in the hyporheic zone of a gravel stream. Limnol. Oceanogr., 45, 1000-1005

Sidle, R.C., Sasaki, S., Otsuki, M., Noguchi, S. \& Nik, A.R. 2004. Sediment pathways in a tropical forest : effects of logging roads and skid trails. Hydrol. Process., 18, 703-720.

Soulsby C., Malcolm I.A. \& Youngson A.F. 2001. - Hydrochemistry of the hyporheic zone in salmon spawning gravels : a preliminary assessment in a degraded agricultural stream. Reg. Riv. Res. Manag., 17, 651-665.

Stevens M.H.H. \& Cummins K.W. 1999. - Effects of long-term disturbance on riparian vegetation and in-stream characteristics. J. Freshwat. Ecol., 14, 1-17.

Stone M.K. \& Wallace J.B. 1998. - Long-term recovery of mountain stream from clear-cut logging: the effects of forest succession on benthic invertebrate community structure. Freshwater Biol., 39, 151-169. 
Strayer D.L., May S.E., Nielsen P., Wollheim W. \& Hausam S. 1997. - Oxygen, organic matter and sediment granulometry as controls on hyporheic animal communities. Arch. Hydrobiol., 140, 131-144.

Tachet H., Richoux P., Bournaud M. \& Usseglio-Polatera P. 2000. Invertébrés d'eau douce: systématique, biologie, écologie. CNRS Eds, Paris, 588 p.

Thioulouse J., Doledec S., Chessel D. \& Olivier J. M. 1995. - ADE software: multivariate analysis and graphical display of environmental data. Pages 239-247 in Software per l'Ambiente Guariso G. \& Rizzoli (eds). Bologna, Italy.

Townsend C.R., Arbuckle C.J., Crowl T.A. \& Scarsbrook M.R. 1997. - The relationship between land use and physicochemistry, food resources and macroinvertebrate communities in tributaries of the Taieri river, New Zealand: a hierarchically scaled approach. Freshwat. Biol., 37, 177-191.

Usseglio-Polatera P., Bournaud M., Richoux P. \& Tachet H. 2000. Biological and ecological traits of benthic freshwater macroinvertebrates: relationships and definition of groups with similar traits. Freshwat. Biol., 43, 175-205.

Usseglio-Polatera P., Bournaud M., Richoux P. \& Tachet H. 2001. A functional classification of bethic macroinvertebrates based on biological and ecological traits: application to river condition assessment and stream management. Arch. Hydrobiol., Suppl $139,53-83$.

Usseglio-Polatera P., Thomas S., Beisel J-N. \& Moreteau J.-C. 1999. - Illustration de la valeur indicatrice des caractéristiques biologiques des macroinvertébrés d'une communauté benthique à différentes échelles d'observation. Ann. Limnol. - Int. J. Lim., 35, 71-80.

Van Herpe \& Troch. 2000. - Spatial and temporal variations in surface water nitrate concentrations in mixed land use catchment under humid temperate climatic conditions. Hydrol. Process., 14, 2439-2455.

Webster J.R. \& Waide J.B. 1982. - Effects of forest clearcutting on leaf breakdown in southern Appalachian stream. Freshwat. Biol., $12,331-344$

Whiles M.R., Brock B.L., Franzen A.C. \& Dinsmore S.C. 2000. Stream invertebrate communities, water quality, and land-use patterns in an agricultural drainage basin of Northeastern Nebraska, USA. Environ. Manage., 26, 563-576.

Wright I.A., Chessman B.C., Fairweather P.J. \& Benson L.J. 1995. Measuring the impact of sewage effluent on the macroinvertebrate community of an upland stream: the effect of different levels of taxonomic resolution and quantification. Aust. J. Ecol., 20, 142-149. 
